\title{
Guarino Guarini and the "Fortificatione" between theory, drawing and design
}

\section{Roberta Spallone}

Politecnico di Torino - Interuniversity Department of Regional and Urban Studies and Planning (DIST), Torino, Italy, roberta.spallone@polito.it

\begin{abstract}
During his stay in Turin as an architect and engineer at the Savoy court, Guarini addresses the issue of fortifications. In those years, in fact, he also works in the field of military buildings, despite being predominantly engaged, both on theoretical and practical ambit, in civil and religious architecture. Dates back to the 1676, the publication of the Trattato di Fortificatione, one of his lesser known works, while his design for the 'Gate of $\mathrm{Po}^{\prime}$ is realized since 1674.

In the Trattato, Guarini proposes a set of rules, based on Euclidean geometry, drawn from observation of several military buildings in France, Holland and Italy. These basic principles provide graphical methods to outline the fortifications plan, during the concept phase. Then Guarini teaches to represent and render three-dimensional images of the conceived fortress.

This paper aims to highlight, using tools of graphic analysis and history of representation, Guarini's contributions to the issue of fortifications crossing information obtained from his theoretical and practical works.
\end{abstract}

Keywords: drawing, design, treatise, graphic analysis, history of representation.

\section{Introduction}

During the long period spent in Turin, from 1666 to 1683, as an architect, engineer and mathematician of Carlo Emanuele of Savoy, Guarino Guarini, Theatines abbot, is very active in the field of theory and architecture, reflecting its large speculative interests and his happy artistic creativity.

In those years, the last of his life, in fact, he publishes several treatises - Euclides adauctus (1671), Modo di misurare le fabbriche (1674), Compendio della sfera celeste (1675), Trattato di Fortificatione (1676), Leges temporum et planetarum (1678) - draws the plates collected in Dissegni d'architettura civile et ecclesiastica (1686) published posthumously as Architettura Civile (1737), realizes civil and religious buildings, among which stand out the Chapel of
Holy Shroud (1667-1682), the Church of San Lorenzo (1670-1679), the Gate of Po (16741690), the Carignano Palace (1679) and, moreover, processes the design of the Consolata Shrine (1678) and the reshaping of the Racconigi Castle (1676-1684). Within this intense activity he has not, as Carboneri notes (Guarini, 1968, p. XIV) stable tasks as military architect, but it certainly has to deal with this matter during his stay in Turin, as well as for drafting the Trattato di Fortificatione also in relation to the construction of the Gate of Po, integrated into the defensive system of 'Torino novo'.

In confirmation of this, in the dedication to the reader, he says: "I've not got less daring license to introduce new forms of fortification, although 
sometimes I designed them, unable to offer them authenticated by experience, which I've never tested or presented them as a product of a talent honed in their research, and shrewd for the defenses of Squares, and between the dangers of arms ... I therefore will offer ancient delineations of Italy, Holland, France, but selected and confirmed by experience, and with the applause of World, nor I will sell my fantastic discoveries, but true and bare rule, that the same Fortresses already put in place, and defenses have solidly given birth, nor I will seek praise, but only education of the reader" ${ }^{1}$ (Guarini, 1676, p. 3).

The short Treatise, in six books and twelve plates placed at the end, is one of the least studied Guarini's theoretical works: there is only an essay on it by Gianni Carlo Sciolla that, in addition to analyzing the content, offers some graphic reconstructions of text and images contained in the plates (Sciolla, 1970).

\section{Geometry and arithmetic for the fortifications' design}

The work of Guarino Guarini, architect, philosopher and mathematician, develops in a century, the Seventeenth, permeated by the 'esprit de géométrie', fueled by discoveries and studies in mathematics and, in particular, in pure geometry, in which is establishing the leading position of geometry within the philosophical method, through the theories by Galileo, Bacon, Descartes, Malebranche and Desargues.

Guarini can be fully inserted, by virtue of his contribution, in the group of scientists that trigger the construction of many scientific disciplines that in the Nineteenth century will reach full maturity (Bianchini, 2008, p. 14).

The breadth and complementarity of speculative interests of Guarini involve the need to read in parallel his writings, not only with regard to its essential contribution to the representation science, but also for his conception of geometry as generator inside the creative process of architecture (Spallone, 1997).

The links between architecture and geometry are evident from the first steps of Architettura
Civile, published posthumously by Bernardo Vittone, where Guarini says: "And because Architecture, as discipline that uses measures in its procedures, depends from Geometry, and wants to know at least its first elements" ${ }^{2}$ (Guarini, 1968, p. 11). Comparing and integrating this excerpt with the definition included in the Placita Philosophica, "Geometry teaches organizing the numbers of the intellect through some kind of argumentations that allow you to find other truths: teaches to arrange the measurements and order them in such a way that from one, through arguments of intellect, others could be found" ${ }^{3}$ (Guarini, 1665, p. 179), geometry seems to be interpreted by Guarini as an ordering criteria of architecture, investing the entire process, from concept to representation and to realization.

On the other hand, since antiquity, mathematics and geometry have played a central role in the definition of beauty (Gregotti, 2008, p. 47).

Guarini's architecture, based on the combination of simple geometric figures reaches, in particular in the domed buildings, highly complex threedimensional solutions, due to a profound geometric knowledge that allows him to address both the problems of intersections between surfaces and solids, which are inherent in the creative sphere of the design process, and their correct representation that becomes the means for the realization, through the projections aimed to stereotomy.

In this regard Argan concludes that Guarini researches stimulus to the imagination in Geometry, and at the same time paradoxical justifications for his fantastic free will (Argan, 1933, p. 396).

Subjecting architecture to the mathematical sciences and connecting continuously the architect's procedures to a rigorous geometric foundation, Guarini stands out resolutely by all previous writers.

Even in his less speculative and practical writings, moreover denounced by the use of vernacular instead of Latin, as the Trattato di Fortificatione, the strict mathematical system, is aimed to derive the military architecture 
techniques from geometry and arithmetic, two liberal arts of the quadrivium. Guarini, in fact, in the first prelude states that "Euclid's Elements are needed by all mathematic sciences... so anyone who wants to advance in the military art, must believe, that this is the basis, the beginning and the first element of which is made up, and on which progresses and grows every reasoning" ${ }^{4}$ (Guarini, 1676, p. 5) and in the second remembers that" To put in plan, and raise the fortresses, quartering armies, and sort them, there are some necessary rules of Arithmetics" ${ }^{5}$ (Guarini, 1676, p. 17).

Only in the following he deepens the theme of military architecture explaining the aim of offering readers a brief treatise (128 pages of text followed by 12 plates) that contains the rules for fortifying sites.

From the beginning of the discourse on Military Architecture Guarini makes use of the construction in plan of a 'regular fortress', using it as a pretext to clarify the essential nomenclature, but especially as exemplum from which to derive the development of subsequent details and their variants.

A careful reading of the first and second chapters of Book I, allowed the author of the present paper to hypothesize not only the sequence of geometric construction, but also to verify the dimensional values of the figure that Guarini draws to illustrate the plan of the regular fortress. Such construction, as will be seen, also presents an extraordinary geometric coincidence with the Citadel of Turin, built between 1564 and 1577 on design by Francesco Paciotto and gradually dismantled by the mid Nineteenth century, while, in terms of the measures, would be slightly smaller than the reconstruction proposed by Daniele Donghi (Donghi, 1894, p. $6)$.

The personal elaboration completes, ideally, the planimetric reconstructions in the essay of Sciolla, for the various types of bastions, proposed in Italy, France, Holland and the two of invention by Guarini (Sciolla, 1970, pp. 524527).
The knowledge of Paciotto's fortification, by Guarinicould be derived, as well as from direct observation, from the fact that he had been called to write some of the captions - those on the Royal Academy, on Piazza Carolina, on the square and Gate of Po (built on his design) - in the Theatrum Sabaudiae that is being printed in Amsterdam and then he could see the accurate plan of the Citadel, which in the layout of the Theatrum follows the perspective view of the Gate of Po.

\section{Geometric sequences for the construction of 'regular fortress '}

"And in this way the first figure is a regular fortress because it is described in a pentagon LPQRS has all the bastions A, B, G, H, I, equilateral and equiangular" ${ }^{6}$ (Guarini, 1676, pp. 34-35).

The construction of the 'regular fortress', in the plate 1 of the Treaty, has been split by the author in fourteen consecutive steps (the last shows a variant of the bastion), suggested, in their sequence, from the discourse developed by Guarini, and reaches a tracing almost the same to the figure accompanying the Treaty (Fig. 1 and tab. 1).

In the discourse Guarini initially uses this figure as a pretext to define, in Chapter I, "The planimetric terms of Military Architecture"7 (Guarini, 1676, p. 33) and, more precisely, the nomenclature of the elements that form the regular fortress and lines of its defense. The different parts that compose the fortress are treated as lines, angles and plane figures. On the other hand, lines and angles are the main object of the Prelude I, in which he anticipates basic knowledge for those who deal with fortifications.

In Chapter II Guarini goes in deep to the topic of the defensive principles of fortress, and here provides some dimensional data for defense lines related to "musket shot" ${ }^{8}$ (Guarini, 1676, p. $33)$ i.e. the range of offensive weapons. 

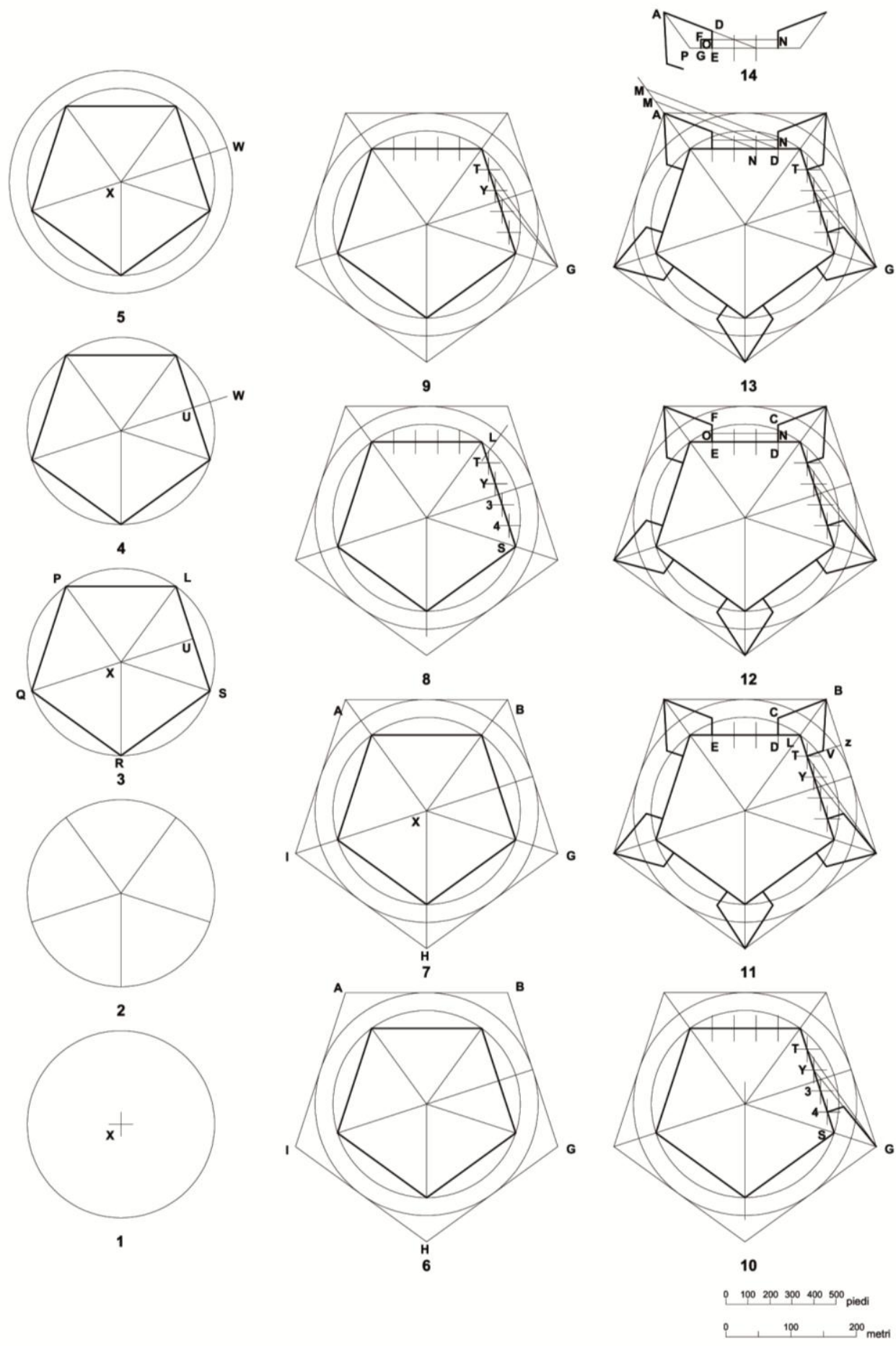

Fig.1- Geometrical sequence of the 'regular fortress' construction. (Drawing by Roberta Spallone). 


\begin{tabular}{|c|c|c|}
\hline n. & Geometric construction & Part of fortress/Nomenclature \\
\hline 1 & Draw a circle with center $X$ & \\
\hline 2 & $\begin{array}{l}\text { Divide the angle whose vertex is the center of the circle into } \\
\text { five equal parts, obtaining angles of } 72^{\circ}\end{array}$ & \\
\hline 3 & Trace the regular pentagon LPQRS and one of apothem XU & $\begin{array}{l}\text { Regular fortress / interior } \\
\text { polygon (Fortezza regolare / } \\
\text { poligono interiore) LPQRS } \\
\text { Side of the fortress } \\
(\text { Lato della fortezza) LP }\end{array}$ \\
\hline 4 & $\begin{array}{l}\text { Extend the apothem with a segment UW equal to twice the } \\
\text { maximum distance from the circumscribed circle of the side } \\
\text { LS }\end{array}$ & \\
\hline 5 & $\begin{array}{l}\text { Trace a circle concentric to the first and having radius equal } \\
\text { to XW }\end{array}$ & \\
\hline 6 & $\begin{array}{l}\text { Trace the pentagon GBAIH circumscribed to circumference } \\
\text { built in step } 5\end{array}$ & $\begin{array}{l}\text { Exterior polygon (Poligono } \\
\text { esteriore) GBAIH }\end{array}$ \\
\hline 7 & $\begin{array}{l}\text { Extend the sides of the angles whose vertex is the center, } \\
\text { getting } \mathrm{XA}, \mathrm{XB}, \mathrm{XG}, \mathrm{XH}, \mathrm{XI}\end{array}$ & Capital line (Linea Capitale) XA \\
\hline 8 & $\begin{array}{l}\text { Divide into five equal parts the pentagon sides LPQRS (see } \\
\text { side LS and points } T, Y, 3,4 \text { ) }\end{array}$ & \\
\hline 9 & Trace segments GT and GY & \\
\hline 10 & Draw a segment orthogonal from point 4 until you meet GY & $\begin{array}{lccc}\text { Secondary } & \text { wing } \text { or side } & \text { (Ala } \\
\text { secondaria } o & \text { fianco) } & \mathrm{TY} \\
\text { Complement } & (\text { Complemento }) & \text { YS }\end{array}$ \\
\hline 11 & Construct as in step 10 the five bastions & $\begin{array}{l}\text { Bulwark (Bastione o balloardo) } \\
\text { BCDTV } \\
\text { Face (Faccia o fronte) BC, BV } \\
\text { Wing (Ala o fianco) CD, VT } \\
\text { Neck (Collo o gola) TLD } \\
\text { Curtain (Cortina o corda) DE } \\
\text { Continued wing (Ala continuata) } \\
\text { TZ }\end{array}$ \\
\hline 12 & $\begin{array}{l}\text { Trace the midpoints of } \mathrm{CD} \text { and } \mathrm{EF} \text {, and connect them with } \\
\text { the segment NO }\end{array}$ & $\begin{array}{l}\text { Bulwark shoulder (Spalla del } \\
\text { balloardo) FO }\end{array}$ \\
\hline 13 & Trace the segments MN, MD, AN & $\begin{array}{l}\text { Line of oblique defense (Linea di } \\
\text { difessa radente) NA } \\
\text { Penetrating line (Linea ficcante) } \\
\text { GT }\end{array}$ \\
\hline 14 & $\begin{array}{l}\text { Extend the segment } \mathrm{NO} \text { and from the midpoint } \mathrm{G} \text { of the } \\
\text { segment PE draw a perpendicular, identifying } \mathrm{F}\end{array}$ & $\begin{array}{l}\text { Ear, variant of the shoulder } \\
\text { Orecchia, variante della spalla }\end{array}$ \\
\hline
\end{tabular}

Tab. 1- Description of the construction steps and building elements generated.

The dimensions given by Guarini are in geometric feet, each of which is equivalent to seven ounces of Piedmont (about $4.28 \mathrm{~cm}$ ); so geometric foot measures about $30 \mathrm{~cm}$. In this sense, it is particularly interesting for verifying the process proposed by the author, the relationship established by Guarini between the curtain and the bulwark; imposing the curtain, in the digital model, the minimum dimension defined by him ( 300 feet), the size of the face of 
the rampart which he describes as about 240 feet, results in the construction carried out about 234 feet. This operation allows you to assess the consistency of the overall proportions of the reconstruction carried out and to appreciate the precision of the original drawing by Guarini (fig. 2).

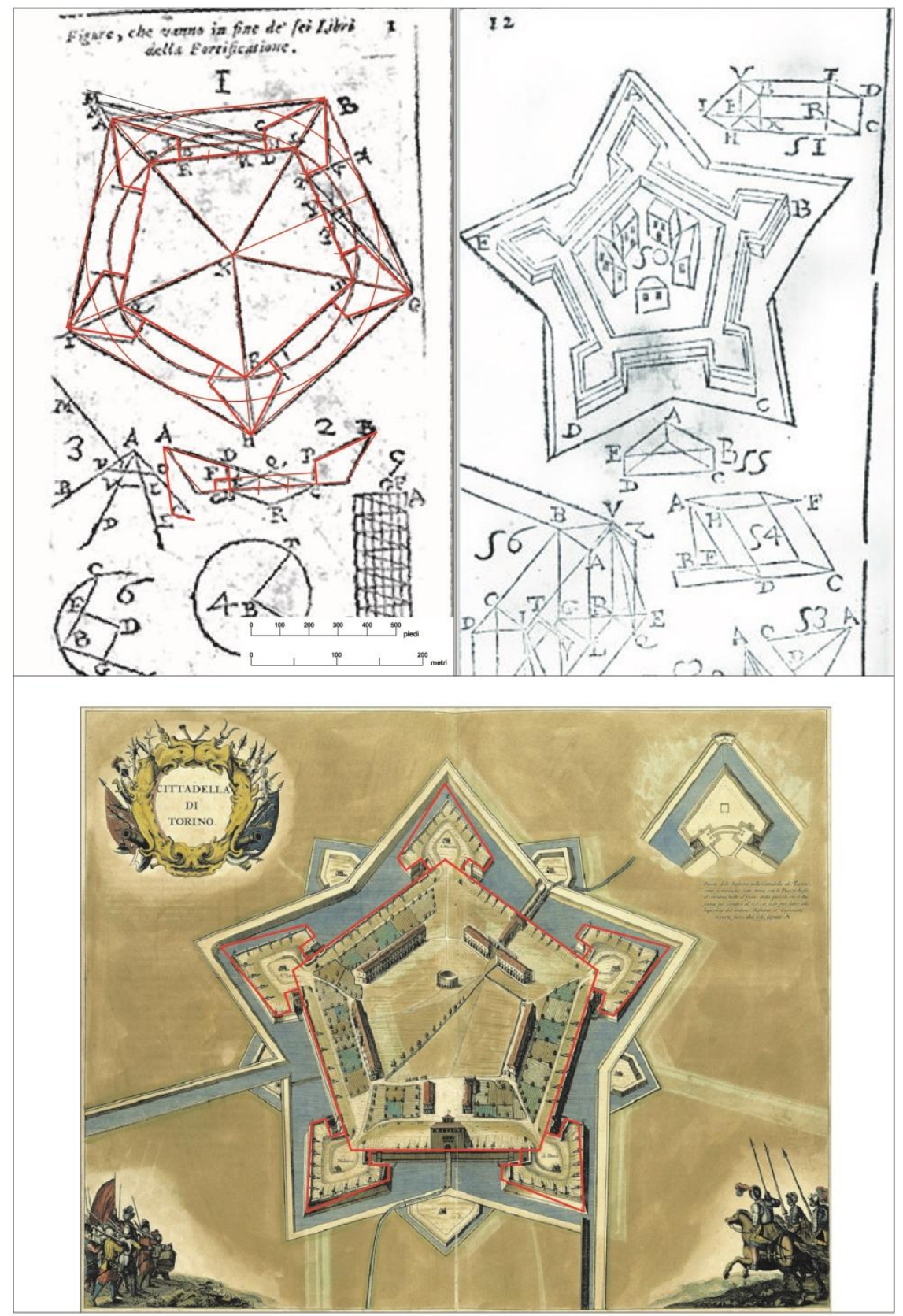

Fig. 2- Overlap of geometric construction to the plan and three-dimensional representation of the ' regular fortress' in the Trattato di Fortificatione. Overlap of the contour of the building to the image of the Citadel of Turin in Theatrum Sabaudiae. (Graphic processing by Roberta Spallone). 


\section{From plan to elevation: methods and techniques of fortress representation}

In the last pages of the Treaty Guarini illustrates the "way of representing by drawing the plan and the elevation of the fortresses, because some people, not being practise in drawing can't understand how the plan drawn matches with the elevation" ${ }^{9}$ (Guarini, 1676, p. 124).

After excluding, for its difficulty, the perspective representation, he shows an expeditious method for the construction of the elevation from the plan, which is nothing more than an empirical application of plan obliques axonometry, widely used, since the early Sixteenth century in military treatises (Scolari, 1984).

In a sort of circular reasoning Guarini proposes its construction of a pentagonal plan equivalent to that shown in Figure 1 of Plate 1, with which he had opened the discourse on the fortifications. Here he ends it, giving material consistency to initial geometric abstraction and representing an image that, again, can be linked to the Paciotto's Citadel. Finally, he completes the statement affirming the superior potentialities of such drawing, compared to the wooden model, which is also used in the ambit of military architecture, since more than two centuries (Scolari, 1988).

In the final chapter of the book, then provides some indication of what today we would call 'rendering', i.e. on shading and color.

The contour of the shadows can be empirically identified by exposing to the natural light coming from a window a book that simulates size and position of the curtain or other parts, and then patterned with brush with "blackened in rubber water with smoke"10 (Guarini , 1676, p. 128).

For the coloring he proposes clear and transparent minium for the walls, pale blue for ditches full of water, or vanished yellow for those in dry, green for earthworks and trenches. It is a iconic type of colorings which, as you can see, corresponds in all to those used in the image of the Theatrum Sabaudiae (fig. 2).

\section{Notes}

(1) "Non mi sono ne meno preso ardimentosa licenza di presentarti nuove forme di fortificare, che pur talvolta ideate mi sono, non potendo porgerle autenticate dall'esperienza, con cui già mai l'ho cimentate, ne vantarle per parto di un'ingegno reso giuditioso nel ritrovarle, e sagace per le diffese delle Piazze, e tra i perigli dell'armi... Io donque ti porgo delineationi d'Italia, d'Olanda, e di Francia antiche, mà scielte, e confirmate con l'esperienza, e con l'applauso d'un Mondo: ne ti vendo i miei fantastichi ritrovati, mà vere, e nude regole, che l'istesse Fortezze gia poste in opra, e diffese, hanno sodamente partorite, ne cerco lodi, ma solo l'instruttione di chi lege" (Guarini, 1676, p. $3)$.

(2) "E perché l'Architettura, come facoltà che in ogni sua operazione adopera le misure, dipende dalla Geometria, e vuol sapere almeno i primi suoi elementi" (Guarini, 1968, p. 11).

(3) "la geometria insegna a disporre i numeri dell'intelletto attraverso un certo genere di argomentazioni, che permettono di trovare altre verità: insegna a disporre le misure ed ordinarle in tal modo che da una, attraverso argomentazioni dell'intelletto, altre se ne trovino" (Guarini, 1665, p. 179).

(4) "Gl'Elementi di Euclide sono si necessarij ad ogni scienza matematica... e per tanto qualonque vuole avanzarsi nell'arte militare, deve credere, che questa sia la base, il principio \& il primo elemento, di cui si compone, e sopra a cui s'avanza, e cresce ogni sua speculatione" (Guarini, 1676, p. 5).

(5) "Per mettere in pianta, \& inalzare le fortezze, acquartierar gli esserciti, \& ordinarli, vi son necessarie alcune regole d'Aritmetica" (Guarini, 1676, p. 17)

(6) "Et in tal guisa la prima figura è una fortezza regolare perché descritta in un pentagono LPQRS à tutti i balloardi A, B, G, H, I, equilateri \& equiangoli" (Guarini, 1676, pp. 34$35)$.

(7) "I termini icnografici dell'Architettura Militare" (Guarini, 1676, p. 33). 
(8) "tiro del moschetto"(Guarini, 1676, p. 33).

(9) "modo di rappresentar in dissegno l'icnografia, e l'ortografia delle fortezze, perché alcuni, non prattici di dissegno, non possono intendere come la pianta dissegnata a parte s'accoppi co l'elevatione" (Guarini, 1676, p. 124).

(10) "acqua di gomma anerita co'l fumo di rasa" (Guarini, 1676, p. 128).

\section{References}

Argan G. C. (1933). "Per una storia dell'architettura piemontese". In L'Arte, XXXVI, 1933.

Bianchini C. (2008). La scienza della rappresentazione nella concezione di Guarino Guarini. Gangemi. Roma.

Bortolotti D. (1840). Descrizione di Torino. Per cura di G. Pomba. Torino.

Cuneo C. (2002). "Il cantiere della Porta di Po di Guarino Guarini". In De Venustate et Firmitate. Scritti per Mario Dalla Costa. Celid. Torino, pp. 338-347.

Donghi D. (1894). "La Cittadella di Torino il suo maschio restaurato e il nuovo giardino Pietro Micca". In Atti della Società degli Ingegneri e degli Architetti in Torino. Camilla \& Bertolero. Torino.

Gregotti V. (2008). Contro la fine dell'architettura. Einaudi. Torino.

Guarini G. (1665). Placita philosophica. Apud Dionysium Thierry. Parigi.

Guarini G. (1671). Euclides adauctus et methodicus, matematicaque universalis. Torino.

Guarini G. (1674). Modo di misurare le fabbriche. Per gl'Heredi Gianelli. Torino.

Guarini G. (1676). Trattato di fortificatione, che hora si usa in Fiandra, Francia, et Italia; composto in ossequio del sereniss. principe Lodovico Giulio cavagliere di Savoia. Appresso gl'heredi di Carlo Gianelli. Torino.

Guarini G. (1686). Dissegni d'architettura civile et ecclesiastica, inventati et delineati dal Padre D. Guarino Guarini. Domenico Paulino. Torino.

Guarini G. (1968). Architettura Civile. A cura di Nino Carboneri e Bianca Tavassi La Greca. Il Polifilo. Milano.

Peyrot A. (1965). Torino nei secoli. Tipografia Torinese Editrice. Torino.

Sciolla G. C. (1970). "Note sul «Trattato di Fortificatione» del Guarini". In Guarino Guarini e l'internazionalità del barocco. Atti del Convegno Internazionale promosso dall'Accademia delle Scienze di Torino. Accademia delle Scienze. Torino, pp. 514-529.

Scolari M. (1984). "Elementi per una storia dell'axonometria". In Casabella, 500, pp. 42-49.

Scolari M. (1988). "L'idea di modello". In Eidos 2, pp. 16-39.

Spallone R. (1997). "La Geometria tra progetto e rappresentazione nell'Architettura Civile di Guarini e in trattati precedenti". In Cigola M., Fiorucci T. (a cura di). Il Disegno di Progetto dalle origini a tutto il XVIII secolo. Gangemi. Roma, pp. 228- 233.

Spallone R. (2006). Il disegno dell'architettura. Perlustrazione critica e lettura interpretativa dai trattati agli scritti contemporanei. Celid. Torino.

Spallone R. (2012). Rappresentazione e progetto La formalizzazione delle convenzioni del disegno architettonico. Edizioni dell'Orso. Alessandria.

Theatrum Sabaudiae. Teatro degli Stati del Duca di Savoia (2000). Archivio Storico della Città di Torino. Torino. 